\title{
The Relation Between Labor Pain with Maternal Anxiety
}

\author{
$1^{\text {st }}$ Nurul Komariah \\ Midwiferry major \\ Politeknik Kesehatan Palembang \\ Palembang, Indonesia \\ nknurulkomariah@gmail.com
}

\author{
$2^{\text {nd }}$ Sari Wahyuni \\ Midwiferry major \\ Politeknik Keehatan Palembang \\ Palembang, Indonesia \\ sariwahyuniplg@gmail.com
}

Corresponding author: nknurulkomariah@gmail.com

\begin{abstract}
Anxiety associated with prolonged labor. A woman who was anxious at delivery can threaten her and her baby's safety. This study was analyzed the relation between labor pain with maternal anxiety. Some studies focus more on primiparas in this study trying to assess without distinguishing parity status. This research crosssectional design. The sample of this study was all maternity women in the 2019 Teti Herawati Independent Practice Midwife at the time of the study and fulfilled the inclusion and exclusion criteria. The sampling technique was purposive sampling. The number of samples was 32 respondents. The data collected was primary data, instrument research, biodata, anxiety questionnaires using The Hamilton Anxiety Rating Scale while for pain assessed by the Comparative Pain Scale. The result showed that there were $22(68.8 \%)$ people who experienced severe anxiety and there were 16 people (50\%) experienced moderate pain. The result of data analysis found that $p$-value 0.028 . P-value $<0.05$ there was a relationship between labor pain with maternal anxiety. Conclusion: Labor pain is something that makes every woman become anxious.
\end{abstract}

Keywords-Pain, Anxiety, Childbirth

\section{INTRODUCTION}

Childbirth is a very spectacular condition in the life of a woman [1]. Many anthropological studies show that the process of pregnancy and childbirth is very important in the life cycles of humans, especially women. "Childbirth is an intimate and complex transaction whose topic is physiological and whose language is cultural [2].

Based on data from the World Health Organization (WHO), it shows that more than 5 million Indonesian women give birth each year and as many as 15.000 died during pregnancy or childbirth. Global data shows that $80 \%$ of the causes of death was caused by five main obstetric causes that can directly caused death, namely postpartum Haemorrhage, infection, unsafe abortion, eclampsia and prolonged labor [3]. Based on data from the Indonesian Demographic and Health Survey (SDKI) in 2012, the maternal mortality rate in Indonesia reached 359 per 100.000 live births. The causes of maternal death were bleeding (32\%), hypertension $(25 \%)$, prolonged labor $(5 \%)$, infection (5\%), abortion (1\%) and other caused (32\%). Prolonged labor was the third leading causes of maternal death in Indonesia. Incidence of prolonged labor in 2007 and 2012 remained the same at 5\%[4].

Maternal anxiety is associated with prolonged labor [5] Adam states that the duration of labor is longer in women who are afraid than women who are not afraid [6]. Maternal anxiety labor[7]. Likewise, the opinion of Amidu (2018) states that anxiety is associated with prolonged labor [8]. Mothers with severe anxiety are related to the length of labor in the first stage [9].

Psychological is a crucial part of labor, characterizedby anxiety or the decreades ability of the mother because of fear to overcome labor pain[10]. The labor process is a tiring and risky event, it is not suprising that candidates who will give birth are shrouded in fear, panic and nervousness. A woman who was anxious at delivery can threaten her and her baby's safety. Anxiety also causes a decrease in blood flow to the uterus, decreased uterine contractions, the duration of the first stage, decreased blood flow to the plasenta, low oxygen available to the fetus[11]. 
Pain during childbirth is one thing that makes mothers worried[12]. Based on preliminary studies of 10 women who experienced labor pain and always ask how were we doing, very sick, it okay? Always asking if you have advanced before opening. They are worried about childbirth. Some studies focus more on pirmiparas. In this study, trying to assess without distiguishing parity status. The Aims of this study was to analyze the relationship between labor pain with maternal anxiety. This study hypothesis was relationship between labor pain with maternal anxiety.

\section{METHOD}

This study used a cross sectional reseach design. The studypopulation was all women childbirth at Teti Herawati. The study sample was all women giving birth at Teti Herawati at the time of the study and fulfilled the inclusion and exclusion criteria. Inclusion Criteria:

Agree to participate in this research First phase active Exclusion criteria:

Single parent

Had complications Got induction of labor.

The sampling technique was purposive sample. The number of samples of this study were 32 people. Techniques collected data were questionnaire and guided interviews. This was primary data. The instrument which used were 3 types questionnaires. There were biodata, Comparative Paint scale and Hamilton Anxiety Rating Scale (HARS).

Anxiety can be measured by measuring the level of anxiety according to anxiety measuring deviced called HARS (Hamilton Anxiety Rating Scale). The HARS scale is measurement of anxiety based on the appearance of symptoms in individual experiencing anxiety. According to observed was divided a 5 level score between (0) zero percent to 4 (severe).

The HARS scale was first used in 1959, which was introduced by Max Hamilton and has now become standards in the measurement of anxiety, especially in trial clinical studies. The HARS scale has been proven to have high enough validity and reliability to measure anxiety in trial clinical studies of 0.93 and 0.97 . This condition indicates that the measurement of anxiety using the HARS scale will obtain valid and reliable results. The way to assess anxiety was to give a rating bycategory:[13].

$$
\begin{aligned}
& 0=\text { no symptoms at all } \\
& 1=\text { one of the symptoms } \\
& 2=\text { moderate/ half of the symptoms } \\
& 3=\text { weight } / \text { more than } 1 / 2 \text { symptoms } \\
& 4=\text { Very severe all symptoms are present }
\end{aligned}
$$

Determination of the degree of anxiety by adding up the scores and items 1-4 with the results:
a. Scoreless than $6=$ noanxiety
b. Score 7-14 = mild anxiety
c. Score $15-27=$ moderate anxiety
d. Score more than $27=$ severeanxiety

\section{Comparative Pain Scale [14].}

On the pain scale, we can find out the level of pain we face:

a. On the scale of 0 (no pain) there is no pain

b. On the scale of 1 (very mild) pain is almost not felt

c. On the scale of 2( uncomfortable) like a mildpinch

d. On the scale of 3(tolerable), pain is felt, like a blow to the nose

e. On the scale of 4 (sad) strong, deep pain like a toothache.

f. On the scale of 5 (very sad) strong, deep, piercing pain such as spained ankles.

g. On the scale of 6 (intense) strong, deep pain, stabling pain is so strong. Unfocused communication isdisrupted.

h. On the scale of 7 (very intense), strong, pain that partially dominates your senses. Affect your clear thinking.

i. On the scale of 8 (terrible), pain is so strong that you can no longer think clearly and often experience personality changes.

j. On the scale of 9: torture unbearable, pain is so strong immediate relief of pain no matter what.

k. On the scale of 10: unimagible and unexplained pain, pain is so intense and unconscious.

Grouping:

1. Scale 1-3 mild pain

2. Scale 4-6 moderate pain

3. Scale 7-10 severe pain

The method of data collection, after the permit process was completed and then the researcher gave informed consent and then maternity questionnaire was given. After that,it was determined whether the mother can be a respondent of this study (judging by the inclusion and exclusion criteria). Next, respondent assessed the pain of labor with CPR and conducted interviews to assessed their anxiety using HARS. The univariate analysis in this study was the frequency distribution while the bivariate analysis was Chi-Square was still responsive (opening 47), beneficence (risk does not exist compensation) and Justice (does not distinguish between respondent). 


\section{RESULTS}

The results of this study were in table 1.1. shows the characteristics of research respondent.

\section{Table 1. Characteristic of subject}

\begin{tabular}{|c|c|c|}
\hline Variable & $\mathbf{N}$ & $\%$ \\
\hline \multicolumn{3}{|l|}{ Education } \\
\hline -Basic & 12 & 37.5 \\
\hline -Middle & 19 & 59.4 \\
\hline -High & 1 & 3.1 \\
\hline Amount & 32 & 100 \\
\hline \multicolumn{3}{|l|}{ Occupation } \\
\hline - Work & 6 & 18.8 \\
\hline - Housewife & 26 & 81.2 \\
\hline Amount & 32 & 100 \\
\hline \multicolumn{3}{|l|}{ Childbirth companion } \\
\hline - Husband & 24 & 75 \\
\hline - Family & 7 & 21.9 \\
\hline - No one & 1 & 3.1 \\
\hline Amount & 32 & 100 \\
\hline Parity & 27 & 84.4 \\
\hline - Multipara & 5 & 15.6 \\
\hline - Primipara & 32 & 100 \\
\hline \multicolumn{3}{|l|}{ Amount } \\
\hline Anxiety & 22 & 68.8 \\
\hline -Moderate & 5 & 15.6 \\
\hline -Severe & 32 & 100 \\
\hline \multicolumn{3}{|l|}{-Very Severe Amount } \\
\hline & 1 & 3.2 \\
\hline Labor Pain & 15 & 46.9 \\
\hline - Mild & 16 & 50 \\
\hline - Moderate & 32 & 100 \\
\hline - Severe & & \\
\hline Amount & & \\
\hline
\end{tabular}

Based on table 1. Showed that as many as 19 people $(59,4 \%)$ of respondent had secondary education. As many as 26 people $(81.2 \%)$ of respondents did not work. More than half of childbirth attendants are accompanied by 24 husbands $(75 \%)$. The parity status in this study was 27 people $(84,4 \%)$ multipara. As for the anxiety level of 22 people $(68.8 \%)$ severe anxiety, labor pain as many as 16 people $(50 \%)$ expericend severe labor pain. The relation between labor pain with maternal anxietycan be seen in the following table.

Table 2. The Relation between labor pain with maternal anxiety

\begin{tabular}{lllccc}
\hline \multicolumn{5}{c}{ Anxiety } & \\
\hline & Moderate & \multicolumn{1}{c}{ Severe } & $\begin{array}{c}\text { Very } \\
\text { Heavy }\end{array}$ & $\mathrm{P}^{*}$ & $\mathrm{X}^{2}$ \\
\hline Pain Labor & & & 0.028 & $\begin{array}{c}10.84 \\
*\end{array}$ \\
\hline - Mild & $1(100 \%)$ & 0 & & & \\
- Moderate & $4(26.7 \%)$ & $10(66.7 \%)$ & $1(6.7 \%)$ & & \\
- Severe & 0 & $12(75 \%)$ & $4(45 \%)$ & & \\
Amount & $5(15.6 \%)$ & $22(68.8 \%)$ & $515.6 \%)$ & & \\
\hline
\end{tabular}

${ }^{*}$ Chi-Square test
But makes the inconvenience for the respondent given In table 2 showed that of the 16 respondents who experienced severe pain 12 people were severe anxiety and 4 people very severe anxiety. The analysis showed that the p-value $0.028<0.05$, there was a relationship between labor pain with maternal anxiety.

\section{DISCUSSION}

This discussion will discuss labor pain, maternal anxiety, and the relation between labor pain and maternal anxiety. The pain experienced during labor is unique and natural process whose mother feel when childbirth [15].

\section{Labor Pain}

Labor pain is physiological process, although other types of pain are always caused by an accident or disease [16]. Labor pain is a subjective with uterine contractions, cervical canal dilatation, and cervical thinning, and fetal decline during labor [17].

Labor pain is felt as radiation that crosses the uterus from the fundus region to the back. Although the levels are different, everyone has experienced pain during labor with different reaction [18]. Labor pain exceeds pain when a person experience an illness. Prolonged labor pain causes hyperventilation with a respiratory frequency of 60-70 times per minute, thereby reducing maternal $\mathrm{PaCO} 2$ levels and increasing $\mathrm{PH}$. When maternal $\mathrm{PaCO} 2$ levels are low, it causes slow deceleration of fetal heart rate. Pain also causes uncoordinated uterine activity which will result in prolonged labor, which can ultimately threaten life and mother [19].

Labor pain has two components: visceral and somatic. Visceral pain is caused by cervical dilatation and stretching of the uterine segment and distention of the uterine corpus. At each contraction thereby activationg excitatory afferent noriceptor partly caused ischemia in the uterus due to contractions[20].

The resulting impulses are delivered to the spinal cord by small afferent fibers without myelin that travels with sympathetic fibers through the pelvic flexus to the hypogastric medium nerve, then spread to the superiorhypogastric to the lumbar sympathetic. Pain fibers from the sympathetic chain enter the dorsal cornu associated with spinal nerves T10 through L1 and pass through the posterior nerve roots to synapses in the dorsal cornu of the spinal cord. Several synaps cross over the dorsal cornu with extensive rostral and caudal extensions causing localized pain in the lower abdomen [21]. Somatic pain occurs when approaching the first stage 
of labor, is painful and localized to the vagina, rectum, and perineum so that painis dominated by tissue damage in the pelvis and perineum. Somatic pain radiates to adjacent dermatomes $\mathrm{T} 10$ and $\mathrm{L} 1$ and when compared with visceral pain, is more resistant to pain reducing drugs. Pain in the second stage of labor [20], [21].

All nerve impulses produced (visceral and somatic) radiate to the horn cells then are processed and transmitted to the brain via the spinothalamic channel. Transmission to the hypothalamus and limbic system contributes to the emotional and autonomic responses associated with pain. So the pain during labor gives emotional experience and presents psychological challenged for many mothers [20] [21].

\section{Maternal Anxiety}

Anxiety is a universal human experience and a feeling that is not expressed because of a source of threats or thoughts that are unclear and not identified, anxiety is closely related of uncertainty and helpness characterized by feelings of fear or deep concern. Anxiety is part of the emotional response to the subjective whose circumtances are influenced by the subconscious. Anxiety and fear will cause stress [22].

In table 2 showed that of the 16 respondents who experienced severe pain 12 people were severe anxiety and 4 people very severe anxiety. The analysis showed that the p- value $0.028<0.05$, there was a relationship between labor pain with maternal anxiety.

Anxiety before delivery is commonly experienced by mother [22]. Although childbirth is a physiological thing, in dealing with the birth process, there is a series of physical and physiological changes starting from uterine contractions, dilatation of the birth canal, and removal of the baby and placenta, which end with the initial bounding between mother and baby [23]. Concerns and anxieties were felt by the mother namely from the emergence of questions and images of the mother whether the labor will go smoothly, whether the baby will be safe or not, and the views of the community who still think that childbirth is a gamble of life and death [24].

Childbirth is a natural process experienced by a woman. As long as the physical condition is adequate, there will not be many difficulties, but not every woman will always be ready to face labor because labor is accompanied by pain and blood loss. Unpreparedness will cause fear and anxiety in the mother especially in women who are childbirth for the first time because in general, they do not have experience at the end of pregnancy, especially in labor, anxiety will mobilize individual defences. How individuals defend themselves against anxiety can be seen from the symptoms that determine the type of disorder[25].

The level of maternal anxiety will affect the length of labor because feelings of anxiety experienced by the mother during labor can stimulate the hypothalamus as the center of the emotional governing limbic system [26]. Anxiety in the first maternity mothers could have an impact on increasing adrenaline secretions. One effect of adrenaline is contrictions of blood vesselsso that oxygen supply to the fetus decreases[26].

Decreased blood flow also causes weakening of uterine contractions and results in prolonged labor. Not only the adrenaline secretion increases but ACTH (Adrenocorticotropic hormone) secretion also ncreases, causing an increase in serum cortisol abd blood sugar levels. Anxiety become from person pain reactions. This will athetic nerve activity and increase caecholamine secretion. Excessive catecholamine secretion will cause a decrease in blood flow to the placenta thereby limiting oxygen supply as well as decreasing the affectiveness of uterine contractions which can slow the laborprocess[27].

Anxiety can cause excessive release of the hormone catecholamine can cause smooth muscle tension and vasoconstriction in blood vessels so that there is a decrease in uterine contractions that allow the emergence of prolonged labor[28].

\section{The relation between labor pain with the maternal anxiety}

In this study, the results showed that there was a relation between labor pain with maternal anxiety. The results of this study are in line with research conducted by Klomp et al, in the Netherlands in 2013, stated that $85.5 \%$ of Primigravid had not received any action or treatment to reduce labor pain. The presence of pain during childbirth increases anxiety in mothers[29].

Unberable labor pain can cause stress and anxiety. The relation between pain and anxiety is complex. Anxiety often increases pain perceptions, but pain also gives rise to a feeling of anxiety [30]. The cause of anxiety in labor is due to the mother's fear of birth defects. Anxiety as a result of labor pain[31]. Pain that occurs can affect the mother's condition in the form of fatigue, fear, worry, and stress. The pain in labor made mothers complain about must be anticipated, the pain caused by childbirth can be concluded into several things, including psychological affects: suffering, fear and 
anxiety [32].

Pain in childbirth can cause anxiety and fatigue in the mother resulting in a negative influence on the progress of labor and fetal well being [33]. Pain is defined as a sensory message from peripheral tissue trauma that is "Specifically and accurately" encoded in the peripheral nerve, transmitted in the center of the nerve pathway, and translated in the brain. The impact of pain will cause metabolic stress response which will affect all body systems and aggravate the patient's condition and will result $\mathrm{n}$ changes in physiology and psychology one of which is cognitive change, anxiety, fear and others [34], [35].

Labor pain is the most significant source of discomfort during childbirth so that it can produce pain levels that often exceed the limits of physical endurance. Pain in labor arises due to psychological responses and physical reflexes. The pain will have an impact on increasing the activity of the sympathetic nervous system which can result changes in blood pressure, pulse, breathing, and skin color, nausea, vomiting, and excessive sweating. Changes in certain behaviors due to pain are also often seen as increased anxiety with thoughts that are narrowed groaning, crying, hand movement and warm muscle tension throughout the body [36].

Ptter \& Perry (2006), reported evidence that pain stimuli activate parts of the limbic system can process a person's emotional reactions to pain, which is to aggravate or eliminate pain. The limbic system can process a person's emotional reactions to pain. The limbic system then stimulates the hypothalamus and causes the secretion of he hormone corticotropinreleasing hormone (CRH) [37].

This wil cause an increase in the production of the Sympathetic Adrenal Modular Axis (SAM), with the response causing stimuli in the pathway of the Pituatary Adrenal Axis (LHPA), then stimulating the hypothalamus and causing the secretion of the CRH, This cause the activation of Adeno Corticotrophin Hormone (ACTH) which will stimulate the production of cortisol hormone from the adrenal cortex. In addition, it will cause activation of adrenergic neurons from Locus Cereleus (LC). Where LC is the site of Noreepineprine production which then secretes epineprhrine [38].

Several studies show that the release of NE plays an important role in fear, anxiety. Some tyes of learning about emotional, memory depend on noradrenergic stimulation of $\beta$ and $\alpha$, adrenoreceptors in the basolateral nucleus of the amygdala. The activity of the norepinephrines the body and brain produce physical symptoms of anxiety such as sweating, and palpitations, which can cause people to become worried [37], [38].

\section{CONCLUSION}

Labor pain is something that makes a women anxious. The advice that can be given to husband and family to provide pain management so that mother can childbirth safety and confortable. Besides that, midwife must starting from pregnant women to build the perception that pain is a physiological thing. So, mother does not worried about childbirth and the baby. Mothers are advised in order to calm down, relax and pray.

\section{ACKNOWLEDGMENT}

The author is gratefull to Polytechnic of Health Ministry of Health Palembang.

\section{REFERENCES}

[1] Efendi F, Chen C, Nursalam N, Indarwati R. Lived experience of Indonesian nurses in Japan: A phenomenological study 2016. https://doi.org/10.1111/jins.12108.

[2] Normal birth as a measure of the quality of care Evidence on safety, effectiveness and women' s experiences. n.d.

[3] Who E, Group WB. Trends in Maternal Mortality: 1990 to 20152015 .

[4] Penelitian B, Pengembangan DAN. RISET KESEHATAN DASAR 2013.

[5] Novelia S, Sitanggang TW, Yulianti A. Effects of Yoga Relaxation on Anxiety Levels among Pregnant Women 2018;8:86-95.

[6] Adams SS, Eberhard-gran M, Eskild A. Fear of childbirth and duration of labour: a study of 2206 women with intended vaginal delivery 2012:15-8.https://doi.org/10.1111/j.14710528.2012.03433.x.

[7] Koelewijn JM, Sluijs AM, Vrijkotte TGM. Possible relationship between general and pregnancy-related anxiety during the first half of pregnancy and the birth process: a $\begin{array}{lll}\text { prospective } & \text { cohort } & \text { study }\end{array}$ https://doi.org/10.1136/bmjopen-2016-013413.

[8] Amidu N, Alhassan M, Issah H, Yakong VN, Yahaya W, Adams Y, et al. Perceived Stress and Anxiety in Women during Labour: A Case of Tamale West Hospital, Tamale , Ghana $2018 ; 11: 1-10$ https://doi.org/10.9734/AJMAH/2018/40373.

[9] Lubis N.L. No Title. Jakarta: 2013.

[10] Maranung. No Title. Jakarta: 2016. [11] No Title 2015:0-23.

[11] Kinney DK, Munir KM, Crowley DJ, Miller AM. Neuroscience and Biobehavioral Reviews Prenatal stress and risk for autism 2008;32:1519- 32. https://doi.org/10.1016/j.neubiorev.2008.06.004.

[12] Wikipedia. No Title. n.d.

[13] EDS Awareness. No Title. n.d.

[14] Lilin E, Lavender A, Perubahan T, Nyeri I, Kala N, Aktif IF. Efek Lilin Aromaterapi Lavender Terhadap Perubahan Intensitas Nyeri Persalinan Normal Kala I Fase Aktif Pada 2015;7:95-103.

[15] Arifin. No Title. 2008.

[16] Wijayanti MA, Transurethral P, Of R, Prostate T, Rumah D, UmumS. Daftar pustaka 2013:2008-10. 
[17] Judha M. http://repository.unimus.ac.id 2013:2008-9.

[18] Widiawati I. No Title. Tasikmalaya: 2018.

[19] Xavier T, Viswanath L. Effect of Music therapy on Labor Pain among Women in Active Labor Admitted in Tertiary Care Hospital Kochi 2016;3:444-8. https://doi.org/10.16965/ijims.2016.145.

[20] Maisaroh EN, Psikologi F, Islam U, Agung S. RELIGIUSITAS DAN KECEMASAN MENGHADAPI UJIAN NASIONAL ( UN ) RELIGIOSITY AND NATIONAL EXAMINATION ( UN ) ANXIETY AMONG STUDENTS 1907:78-88.

[21] Agency C. Jurnal SIKLUS Volume 07 Nomor 02 Juni 2018 PADA IBU HAMIL PRIMIGRAVIDA TRIMESTER III Jurnal SIKLUS Volume 07 Nomor 02 Juni 2018 2018;07:300-6.

[22] No Title 2012;1:2007-9.

[23] Erawati. No Title. 2010.

[24] Maramis. No Title. Surabaya: 2015.

[25] Hayati F, Herman RB, Agus M. Artikel Penelitian Perbedaan Tingkat Kecemasan Ibu Bersalin di Puskesmas dengan di Bidan Praktik Mandiri dan Hubungannya dengan Lama Persalinan n.d.;6:564-71.

[26] Fatikhah. No Title. Semarang: n.d.

[27] Davim. No Title. 2007.

[28] Klomp T, Jonge A De, Hutton EK, Lagro-janssen ALM. Dutch women in midwife-led care at the onset of labour: which pain relief do they prefer and what do they use ? 2013.

[29] Potter \& Perry. No Title. 2007.

[30] Christanto FA, Susilo TD, Windrawanto Y. Effect of selfconfidence on high school student 's social adjustment n.d.;51:110-4.

[31] No Title 2013:2009-11.

[32] Maita L. No Title 2013:186-90. [34] Dm F. No Title 2015:2011-3.

[33] Ed H, Downe S, Edwards N, Walsh D. Home-like versus conventional institutional settings for birth ( Review ) 2009.

[34] Sandy P, Imannura U, Budhiastuti UR, Poncorini E. The Effectiveness of Hypnobirthing in Reducing Anxiety Level During Delivery 2016;1:200- 4 .

[35] Devis EP SC. No Title. 2012.

[36] Martin EI, Ressler K. The Neurobiology of Anxiet $y$ Disorders : Brain I maging, Genetics, a nd Psychoneuro endo crinology 2009;32:549https://doi.org/10.1016/j.psc.2009.05.004. 